\title{
Memoir and the Re-reading of Fiction: Rudy Wiebe's of this earth and Peace Shall Destroy Many
}

\section{ABSTRACT}

Canadian novelist Rudy Wiebe's award-winning memoir, of this earth: A Mennonite Boybood in the Boreal Forest (2006), invites readers into a warm subjective realm in which a meditative Wiebe (b. 1934) recounts his growing-up years from birth to age thirteen. As self-reflexive "rememberer," Wiebe explores the sensate freshness of a boy's ways of seeing, touching, and, not least, hearing the world. The young Wiebe lives with his parents and siblings and neighbours in an emotionally warm Christian community of 1920s immigrants to Canada who have fled from the Soviet Union in the wake of the 1917 Revolution and who struggle for economic survival in a remote corner of rural Saskatchewan during the 1930s and 1940s. But Wiebe's memoir of childhood is not only autobiography and social history; it is also a linguistic text that subtly invites readers to look beyond its textual boundaries to his earlier work. In particular, it has the effect of carrying alert readers back to the setting-at least physically and geographically if not altogether socially and culturally_of Wiebe's first novel, Peace Shall Destroy Many (1962). That early novel was a caustic work notoriously controversial especially among Mennonite readers in Canada when it appeared almost a half-century ago. The 2006 memoir - with intertextual allusion-invites readers to recall especially one layer of that early novel barely noticed by readers, a layer eclipsed and partially hidden by the dominant narrative. Specifically, it invites readers to see the virtually sinless and prelapsarian world of the idealistic young Hal Wiens whose idyllic life in the fictional spaces of Peace Shall Destroy Many goes unnoticed because it is so very much in the shadow of the doubts and tensions that inform the much larger world of his spiritually troubled older brother, nineteen-year old Thom Wiens. The memoir pushes readers into re-thinking the reception of that novel, and into finding anew beneath its severe and satiric treatment of the aus- 
tere adult world the linguistic and spiritual joy of life given shape in the playful perceptions of the young $\mathrm{Hal}$. The memoir becomes a stimulus for a transformational re-reading of the novel. This essay explores the two works in light of each other and of conventions that govern the two respective genres. It attempts, also, to account for the reading strategies that Wiebe's 2006 memoir proposes to readers of his first novel, and for key influences informing the two respective works.

\section{Abstract}

We shall not cease from exploration

And the end of all our exploring

Will be to arrive where we started And know the place for the first time. (T.S. Eliot, "Little Gidding”)

"That was so long ago, it is almost no longer so," is the English version of the "Mennonite proverb" that Canadian novelist Rudy Wiebe (b. 1934) uses as one of the two epigraphs to his award-winning 2006 memoir, of this earth: A Mennonite Boybood in the Boreal Forest. The epigraph is rooted in the Low German of Wiebe's people, people who in the late 1700s moved from the Vistula Delta (where they had moved 200 years before from the Netherlands) to Russia and (as in the case of his parents) to Canada between 1923 and 1930: "Daut wia soo lang tridj, daut es meist nijch meea soo." His second epigraph is from “Conversation \#2," taken from Robert Kroetsch's The Snowbird Poems: "What do you do for a living, I asked. / I remember, she replied."

1 In a Foreword to his novel Peace Shall Destroy Many, Wiebe provides a one-page description of the historic origins of the Mennonites in the novel, who stem from early Anabaptists: "The Anabaptists of the sixteenth century were the extreme evangelical wing of the Reformation movement. The name 'Mennonite' was early attached to them, after Menno Simons, their sole early theological leader to survive persecution. . . . They were driven from Switzerland to America, from Holland and northern Germany to Prussia, then Russia, finally to North and South America. Wherever they went they carried peculiar customs, a peculiar language, a peculiar faith in the literal meaning of the Bible. ... The Mennonites portrayed in this book... could belong to any one of several groups that came to Canada from Russia in the 1920s." These are also the Mennonites of of this earth.

In 2007 Wiebe won the $\$ 25,000$ Charles Taylor Prize for Literary Non-Fiction for of this earth. During his career Wiebe, who has received many honours, has twice won the Canadian Governor General's Award for Fiction: in 1973 for his novel The Temptations of 
With these epigraphs drawing attention to remembering and narrating, Wiebe invites the reader to move forward into the warm subjective interiority of his memoir, where he recounts his growing-up years, from birth to age thirteen. It is a memoir suffused in fantasy-like beauty and delicate softness, with the adult "rememberer" (re-)constructing the sensate freshness of a child's ways of seeing, touching, and, not least, hearing. It is, at the same time, a memoir of a Christian community of a sort that is ideal for a growing child: safe, sensitive, generous, supportive, hard-working, spiritually and socially stimulating, emotionally warm and accepting.

Surprisingly, however, and without overt warning of any kind, with these epigraphs Wiebe, in taking us forward, simultaneously invites us to look back. Through gestures of intertextuality within the memoir, he nudges us into considering one of his literary worlds that has largely bypassed readers' attention, most crucially the world of the child in his first

Big Bear; in 1994 for his novel A Discovery of Strangers. This year (2009) Wiebe, who lives in Edmonton, Alberta, received the \$30,000 Lieutenant Governor of Alberta Distinguished Artist Award. Wiebe is a Member of the Order of Canada.

My essay is based on my presentation to a special session on Canadian Mennonite Literature organized by the Christianity and Literary Study Group and held at the annual meetings of the Association of Canadian College and University Teachers of English in May 2009 at Carleton University in Ottawa. It echoes some of the concerns about subjectivity, identity, and naming in my earlier essay, "The Naming of Rudy Wiebe," Journal of Mennonite Studies 7 (1989): 115-22 (which was published also in Short Fiction in the New Literatures in English. Ed. Jacqueline Bardolph. Nice: 1989. 133-39). It is a companion essay to my recently-published " $[\mathrm{T}]$ here are certain things Mennonite children are kept from seeing': Sexuality, Seeing, and Saying in Rudy Wiebe's of this earth and Peace Shall Destroy Many," Journal of Mennonite Studies 26 (2008): 133-42. There I explore, in part, Thom's yearning for a discourse concerning matters of sex and romance: "Words about sex in Peace Shall Destroy Many emerge, when they emerge at all, only indirectly, in fits and starts, sometimes furtively and slyly, sometimes obscenely and vulgarly. Any tender words about sex, about sexual attraction, are sought in vain by the protagonist, Thom Wiens, for the language of tender expression remains an inexpressible fantasy. When Thom wants to speak with his pal about a girl he finds attractive, 'to merely talk about her in an uninhibited manner as about anyone else,' he finds that the social presuppositions of his world do not admit the structuring or expression of that kind of talk: 'If people would just mention things about her,' he thinks to himself, his mind on the beautiful Annamarie Lepp; 'but single Mennonite men did not talk at length about girls to one another.' Though 'longing desperately' to speak of girls, the two male friends, automatically censoring what they say, turn quickly to 'talking casually about the harvest.' In this first of his major works beginning to write a Mennonite history of sex as a word, a word that cannot be spoken, Wiebe represents the word with a dash, the dash—cold, stiff, detached—providing a chasm representing that which cannot be said. There is, here, no revelling in a liberated sense of the spirit or the senses."

For a detailed study of Wiebe's language, especially his interest in "monoglossic" and "heteroglossic" discourses, see Penny van Toorn, Rudy Wiebe and the Historicity of the Word (Edmonton: University of Alberta Press, 1995). 
novel, Peace Shall Destroy Many. It has bypassed readers' attention because it is a world that he hinted at yet simultaneously held in abeyance fortyfour years earlier, in that 1962 novel. I am thinking of the barely-glimpsed world, in that novel, of young Hal Wiens. The virtually sinless and prelapsarian world of the memoir is a large version of the wondrous world of the idealistic young Hal, but Hal's world is sharply constrained, his voice pinched back. Further, Hal's is a world that is overwhelmingly eclipsed by the severe world of the novel's troubled protagonist, Hal's nineteen-year old brother, Thom Wiens. Thus, we get to know Hal's world fully, as it were, only in the memoir.

The memoir provides us with ingredients and signposts that implicitly or explicitly direct us to that 1962 novel, the meanings of which Wiebe in essence urges us to understand anew. In its entering into conversation with the novel, the memoir gives us the sense that a vital if barely-noticeable subjectivity teems beneath the jagged surfaces of the sternly programmatic bulk and thrust of that austere early novel, a novel concerning the blind language of power and control in a small religious community in a remote corner of Saskatchewan. There, most of our attention is taken up by bitter and confrontational moments along its spiritually stark vistas where cacophonous confusion and conflict of various adult voices prevail. ${ }^{2}$

Whether we let the epigraphs deliver us forward into the 2006 memoir or, in effect, back to selected portions of the 1962 novel, they carry us to the rhythms and cadences of an idyllic world that tugs at our own yearnings for innocence. It is true that Wiebe recognizes that such a world can belong only to the child, and then, to be sure, only to the child recalled by the adult-but nonetheless it is a world that, without irony, he presents and realizes in its fullness in the memoir. It is a world suffused with the wonders of language, and shaped by the sounds of the voice.

Wiebe explains his understanding of a child's relation to languagefirst the sounds, then the meanings-at many points in the memoir. $\mathrm{He}$ suggests that a child at birth falls into a kind of language bath, an "immersion of words" (of this earth 131). Wiebe as memoirist revels in the texture and aura that his family and community and church produced

2 The blurb on the back cover summarizes the concerns of Peace Shall Destroy Many: "Fleeing from privation and hardship in Russia, a small group of Mennonites have settled in the rich farming lands of Saskatchewan during the years of the Depression. The community has thrived, while still adhering to its ancient traditions and beliefs. / Then comes the year 1944 , and into the lives of a people dedicated to peace and non-violence come the increasingly powerful threats and challenges from the war-torn world outside. Through a careful weaving of events, Mr. Wiebe reveals the violence that lurks just beneath the surface in the lives of this Mennonite community. The ebb and flow of times and events and their effect on this intensely religious people are described in passages of power and great vibrancy." 
with the lavish soundscape of their words and songs. He uses limpid layers of language to let words from the past sift through and mingle with his play of words in the present. "Herr, Gott, du bist unsere Zuflucht für und für," he writes in his prologue, "Lord, God, you have been our refuge in all generations." Words such as these from Psalm 90 he heard, read aloud and recited, at home and in church, "before [he] could speak any language" (3). Words were at the heart of the sensory net into which he fell as a child.

In Peace Shall Destroy Many, a parallel soundscape is intermittently present in the ethos that defines young Hal. But it is mainly the world of Thom that we hear and feel in the novel. However, Thom has difficulty in hearing and feeling his own world, so bereft is he of any language that he might require for such understanding. Tragically, the dynamics of the community in which he lives have stripped him of a complexly nuanced and subtly analytical and humanely critical language that he only fumblingly seeks. Hal, younger and not yet any kind of threat to the power structures in the community of the novel, can get away with expressing an excess of unbridled and undisciplined language. For Thom, the community's strict dogma and discipline have led him to a scarcity of words, a shortage of linguistic expression, a paucity of narrative choices, and have reduced the range of his emotional life. ${ }^{3}$

What makes an examination of the novel in light of the memoir particularly compelling and urgent (and, to be sure, ironic) is the essentially autobiographical nature of both texts. The novel's material setting-its place in Saskatchewan, its time, its demographic, and, implicitly, many of its people-is more or less identical to that of the memoir, published 44 years later. Hence, if we come to the exuberant memoir after having read the acerbic novel, we might at first wonder at Wiebe's uninhibited sense of rejoicing-of his awe at the very nature of the grandeur and mystery of existence even in physically difficult times-that is sustained throughout the very long text of the memoir.

But some of the memoir's details - the overlapping subjectivity with the "Hal" portions of the novel, or allusions to parallel images or events in the novel-make clear that Wiebe would have us re-read those portions of the novel and, in the end, re-read and understand afresh the novel as

3 That the dominant trajectory and tone of Peace Shall Destroy Many offer a world at odds with those of the memoir is established by its epigraph, which stands imperturbedly and starkly at odds with the epigraphs of the memoir. Embedding the words of the novel's title, the epigraph is an Old Testament passage, drawn from Daniel 8: "And in the latter time, a king / shall stand up. / And his power shall be mighty / and he shall prosper. / And he shall magnify himself in his heart, / and by peace shall destroy many: / But he shall be broken without hand.” 
a whole. With the memoir, then, Wiebe provides a bold and dramatic invitation to re-think his controversial first novel with which he came to public prominence nearly a half-century ago. It is an invitation to re-enter and explore again certain lyrical layers of the novel where plot and story and narrative trajectory seem to come to a stop, and where poetic utterance, an unbridled embrace of the joy of sensual existence within a natural idyll of sky and tree, wind and water, begin.

$$
* * *
$$

Thom Wiens's interior world, which dominates the novel, is one of painful edges. It is objectified in whatever causes him to stumble when he "feel[s] something abrupt against his boot" (Peace 82) rising out of a swamp just beyond the slough where he and his friend Pete Block are cutting hay. Pete, seeing Thom trip, offers a dully pragmatic response: “Shouldn't be any rocks here in the swamp"' (82). It is, in fact, not a rock, but a skull. Thom, who surmises that it must come from a wood-buffalo, imagines, too, that it might fit in to the story of some unknown Indian hunter decades ago (83). He laments that the words to tell such a story are not accessible to him nor, seemingly, to anyone in Canada: "Not one remembered word of how generations upon generations [of Indians] lived and died" (83). Thom is aware that about "white men" (82) there is a plenteous supply of words in the “stacks of European history books to read" (83).

Pete, at ease with the community's prejudices against Indians, challenges Thom's would-be imaginative flight through space and time and a possible-perhaps golden-Indian past by reducing the focus to the here and now. He scoffs at Thom's yearning for story-telling by scoffing at the Indians on the neighbouring reserve who, he says, would stoop to any kind of subterfuge just to steal five chickens from his dad. Thom is shocked by the incommensurability of the two themes, the infinite vastness of a unique but unknown history against the "conventional triviality" summed up by Pete's anxiety over missing five chickens. But he cannot find the means - the story, any story—to respond to Pete's reductive criteria for understanding an Other. Frustratedly recognizing his incapacity to respond with words, "Thom hurled the skull as far as he could" (Peace 83), so that it might lie safely in the still-unmown hay on the next piece of land, which belongs to his own family, and await the arrival there perhaps of some new language. Pete, held back by his dull imagination, only snorts at Thom, telling him that it will ruin his mower when he runs over it. Thom is filled with anger, but is trapped in his claustrophobic feeling of inarticulate confusion. ${ }^{4}$

${ }_{4}$ The recently departed schoolteacher, Joseph Dueck, who is present in the novel in epistolary and flashback formulations, does provide a model of eloquent articulation 
When Thom's own hay mower later gets caught not on that skull but on the root of a tree, his neighbour, the kindly Pastor Lepp leaves his own mower to come over to help Thom. Suddenly: "Without warning, without looking up, Thom said, "What are the traditions of the fathers?" (Peace 86). The pastor is startled, but nonetheless sympathetically engages Thom in a lengthy conversation about the beliefs and actions of the local church community. Privately, he claims that he wishes for Thom an effective English-language mission in teaching children from the Indian community. However, he declares that, when he speaks from the pulpit on a Sunday, and speaks exclusively in German, he must side with the rigid structures of that community. Thom is startled by the gentle pastor's capacity for moving so illogically and tight-heartedly against his own private sensibilities.

Pastor Lepp and Pete Block, like other adults of Thom's religious community drawn inexorably into the tight orbit of the church, are obsessively controlled by Pete's father, Deacon Peter Block, who polices both the language and the silences in the community. Although both Pastor Lepp and the young Pete Block are at intervals close to the serious and sincere Thom Wiens, they demonstrate soon enough that they belong to the feardriven camp of the "massively domineering" Deacon ("Author" 65). Thom is endlessly stymied by these people who are controlled by Deacon Block, people who produce in him his seething crisis of spirit and conscience, and so alienate and isolate him inside his own tormented mind and body. Wiebe uses the "uncertain ... confused ... ambivalent" Thom to pursue what is for him the "quest for truth" at the heart of the narrative ("Author" 65), but it is a quest that Thom does not have the language to fulfill.

Speaking to an audience at the University of Manitoba's St. John's College twenty-five years after the publication of Peace Shall Destroy Many, Wiebe provided touchstones in the novel that I shall pick up in this essay. He alluded repeatedly to the episode of Thom standing in the hay slough and contemplating the buffalo skull, and seemed to intimate that there was something of the novelist - of an early version of Rudy Wiebe himself, as it were-in that moment. It was a moment that included, for Thom, the rudiments of story-telling, for, as Wiebe put it, "that half-rotted skull does suggest greater possibilities." That moment, with the skull in his

and visionary thought. His spirit hovers over the novel, but he is absent from the narrative diegetic.

It is interesting to note that already in Peace Shall Destroy Many Wiebe alluded to the story of Big Bear (111). In of this earth Wiebe marvels at his ignorance at travelling, without knowing the significance, at age eleven and a half, on a bus alongside Indian lands where Big Bear had been born 120 years before. Yet Big Bear would, says Wiebe, bringing to mind much of his work, including his The Temptations of Big Bear, "someday inhabit half a century of my personal, my writing, life" (of this earth 325). 
hands, lets Thom begin to sense something beyond "mere bone," beyond even the once-massive body of the beast, right to an incipient sense of a world made up of "that surrounding landscape, that air, those particular people [on the reserve] with their desires, their endless human necessities" ("Skull" 20). Wiebe claimed that Thom begins to catch a glimpse, however faint and fleeting, of life beyond the reductively programmed religious absolutes of his community: "Thom in the swamp does what a novelist can do: lends us eyes, ears, tongue" (20). But, overall, the dangerous swamp with its sucking mud and seeping water becomes an image for what keeps Thom from breaking outside the so-called Christian dogma that clings to him and entraps him. For all Thom's seeing, he cannot advance to any kind of significant saying. As Wiebe pointed out to his Winnipeg audience, Thom remained trapped inside a conflict-ridden and claustrophobic world, paralyzed by "suppression and avoidance" (Peace 238)..$^{5}$

When Thom, in some desperation, does cast about for stories by which he might seek some kind of redemption and release, he finds little solace in his searching. His mind flashes back to stories he read in some "pale-blue booklets" buried on the bottom shelf of his scrawny school library-stories of Greek mythology (Peace 84). When the story of Prometheus flashes to mind, he can only see himself as both the giant who has carried the divine fire to man and the eagle eating the giant's liver, "daily ravaging ... the writhing body" (85).

Along with the skull, two other grim images and motifs that leap from the pages in Peace Shall Destroy Many include the story of Elizabeth and her father and of the Christmas pageant that is juxtaposed to the violent episode in the barn. In his twenty-fifth anniversary recollections, Wiebe identified all three-the skull episode, the Elizabeth/Deacon Block relationship, the combination of Christmas-nativity childlike sweetness and futile violence-as belonging to a string of "broken suggestions of stories" that he had written during his student days of the 1950s for Professor F.M. Salter's writing classes at the University of Alberta.

But Wiebe identified also a fourth, that of the two young boys' frog hunt so evocatively told in the first Prelude of the novel. The description

5 Wiebe could not prevent himself from pointing out that Thom, holding the skull, does not attempt to evoke Hamlet, nor the jester Yorick, with an "Alas, poor Bison, I knew him..." ("Skull” 20).

During that anniversary lecture in Winnipeg Wiebe confessed that, once it had appeared in Canada, Peace Shall Destroy Many provided even its author with lessons about words, and became for him "both an exaltation and a trauma" ("Skull" 8): "With my wife and two infant children, I was living in Winnipeg and editing a weekly church paper when Peace Shall Destroy Many was published in September, 1962. By March, 1963, I was no longer editor and by August we had left Canada. O, words have power, power beyond what I had imagined in three years of wrestling with them [while writing that book]" (8). 
of the two young boys, one fair, one dark, on their spring hunt for frogs' eggs (9-10), stands in sharp contrast to the other three. The rhythms are more relaxed, a spirit of lightness and brightness hovers over all.

Wiebe, contextualizing that Prelude in his 1987 recollections, said alluringly:

Perhaps only those who have lived through the cold, the darkness of a northern prairie winter can comprehend the miracle of warm earth and water and spring green leaves and frogs singing; can comprehend the incredible feeling that the bright morning spring air fondling your nostrils releases you into. ("Skull” 11)

With those words Wiebe was, in effect, not only summarizing a minor strand of attentiveness in the novel, but also anticipating his memoir-for the spirit and tone, the rhythm and temper, of the opening Prelude of the novel are, so to speak, carried over into of this earth, where they are vastly expanded. Indeed, in the memoir, it seems like we are held in a carefree world of “lookin' for frogs' eggs again." Descriptions like this one, of the coming of spring-as though taken from Fern Hill_-suffuse the entire memoir:

... one morning the world had rolled over into bright green to the music of frogs singing between the rushes of every flooded slough. The creeks ran loud as ducks gabbling under the plank culverts, and before I was aware of it my creased pants were crumpled from not having been rolled up far enough when I waded in the mossy, sinking slough, muddy and slimed with frogs' eggs. (209)

$* * *$

In the memoir, gone is the anxiety that knots the stomach-never mind the spirit and the soul, the mind and the heart_of the 1962 novel's protagonist Thom Wiens. Gone is Thom's clumsy groping for truth with his awkward mix of "sincerity, uncertainty, confusion, mistakes, and renewed attempts" ("Author" 65). For example, although the troubling heft and burdensome weight given to the five stolen chickens are hinted at, they now romantically link local Indians to the nomadic Bashkirs of Russia. Mildly bothersome details about chickens now become lost in the haze of silly gossip of a "talky" neighbour (of this earth 311).

Gone too, or rather, transformed into lightly-handled vestigial residue, are those three dark elements, wrapped in dour sourness, that I have already taken (if somewhat arbitrarily) from Wiebe’s 1987 list.

First: gone altogether is what Wiebe has called "the fiction that determines the entire body of the novel, ... the story of Elizabeth and her father" 
("Skull" 11). In the novel, Elizabeth dies in the pangs of her secret pregnancy, the result of her sexual union with the Metis hired hand, that she has kept hidden from her hyper-patriarchal father. There are deaths in the memoir, certainly. Especially significant to Wiebe is the death of his dear sister Helen, a death that is described with a sad melancholy, but not with any kind of hopelessness or despair. In the memoir, a conversational Wiebe-relaxing in his own deep sense of personal being, of spiritual and material rootednesssimply trusts his audience with the details of his life. Comfortable with his own control of language, he gives the sad tragedy in the family a cradle for coming to rest within the folds of his gentle recollections. By contrast, in the 1962 novel, Thom's — and by implication, the reader's — route to knowledge is brutal, confrontational, filled with shock, with disgust, and hypocrisies, with false taboos and manufactured fears of transgression.

Second: the pale-blue booklets with their terrifying images of Promethean self-violation are back, but are now filled with the narrator's hilarious day-dreams of Theseus and the Minotaur (203), or his happy experiences of reading and re-reading of "laughing, golden Aphrodite, the irresistible goddess of love and beauty," in love with the "bent and blackened" Hephaestus (212).

Third: a Christmas program followed by violence in a barn (recalling the Christmas program at the end of Peace Shall Destroy Many) is now but a shimmering speculation among nostalgic memories about whether in fact there had been an actual Christmas program during the fall when Wiebe was nine years old. Perhaps there was no teacher at all that termperhaps because there had been some kind of trouble. "It might be that the Christmas concert went wrong, something happened between a soldier on leave and the teacher, in the barn, while Santa Claus was handing out Christmas bags to us little kids," Wiebe says with a deliberate and teasing vagueness (213). For Wiebe-offering readers the persona of a slightly bemused and wise elder statesman, or of the well-tempered memoir writerthere is now no sense of sexual tension, no pained exploration of hypocrisies, power, dogma. Only this casual reflection that includes his hinting at connections between 2006 memoir and 1962 novel: "that may well be a shadow incarnation of the ending of my first novel — but the fact is I can remember neither teacher nor problem" (213).

Wiebe has liberated and revealed and explored fully in his memoir a spirit that only lingered along some of the happier edges of Peace Shall Destroy Many. In the memoir he in effect offers a recuperative reading of the spirit of Thom's younger brother Hal, to whom early reviewers remained, as Hildegard E. Tiessen points out, oblivious. His name, an abbreviated form of Helmut, suggests, in the German, "bright spirit" (Tiessen 171). Hal is a positive force representing renewal for the com- 
munity and, at the end, announcing the end of its isolation, she observes (Tiessen 171-72).

Language flows freely and non-judgmentally for $\mathrm{Hal}$, as it does not for his brother Thom-who is earnest, searching, quick to physical anger, slow to find generous spaces where words can grow and flourish. Hal, playing hooky from school, is the first speaker in that opening Prelude, where he cries out with a jubilant, "Let's go!" (Peace 10). This certainly is not Eliot's "Let us go then, you and I." Racing along barefoot in the field that the agonized Thom is ploughing, and transforming himself from "Indian" to fighter-plane as he runs lightly on the earth, Hal is the first speaker in the narrative proper, too, carrying himself forward in an embodying gush of words. Even a word like "half-breed," commonly used negatively by people in his community, holds no ethical or moral value for $\mathrm{Hal}$ (15). And it is Hal, ever ready to brim with words (on those occasions when we encounter him), who offers the novel's closing benediction. As the Wiens family, Thom at the reins of the cutter, heads home through the icy, clear, anguish-riddled December night, Hal chirps up with his unselfconscious "Wish it was spring so we could go lookin' for frogs' eggs again" (238). "'Yes,' Mrs Wiens said, holding her little boy tightly." At the same time she imagines, with some kind of desperate hope, that Thom, who is "staring skyward," might be "driving them toward the brightest star in the heavens" (Peace 238-39). Wiebe puts strong limits on Hal's wish for spring and Mrs. Wiens's fantasy; right after they have been expressed, he closes the novel by referring to the World War Two backdrop that informs the tone and the issues of the whole work: "Around the world the guns were already booming in a new day" (239).

Wiebe's memoir lets things float more open-endedly and buoyantly in its closing pages. If the idyllic images at the heart of Fern Hill offer continuities with Wiebe's edenic memoir, the mournful ending of Fern Hill, capturing an adult's perspective, does not. Wiebe's memoir ends with affirmations of its celebration of story and word, with him at age thirteen looking ahead to a new phase of life on the southern Alberta prairie whereas in the manner of young Hal's life in Peace Shall Destroy Many-there seems to be space adequate for expressing an infinitude of words:

A seemingly endless land forever open to the visitation of wind. Bracing myself into that breathing wind, I would grow to feel it: a land too far to see, fathomless to the looking eye-but, perhaps, touchable by words.... words forged and bolted together into the living architecture of story. (387) 
Wiebe's memoir becomes a kind of blueprint that maps a re-reading of his first novel. In a metaphoric sense, the memoir is a kind of coming into language for the Hal of the novel. Its open joy in language, from the opening to the closing page, makes all the more palpable and poignant the language crisis that Thom experiences in the novel.

The memoir lets Wiebe explore the dynamic by which a child and words, language, story grow into each other, intuitively, as it were, become as one with each other. It is a child who embodies a fullness of religious insight, absorbing and conveying it in innocence and without question, and-in keeping with the spirit of the Mennonite/Christian community overall, including, astonishingly, all of its adults-certainly without the pain of tormented questioning and questing that Thom endures in Peace Shall Destroy Many. In writing a memoir that enters into the kind of conversation with his first novel that I have here been suggesting, he has written an exhilarating work that a reader of that novel, even a reader attentive to the Hal of that novel, might not have expected, for the memoir is so much more spirited and free-wheeling at multiple levels even than the episodes involving $\mathrm{Hal}$ in the novel. In the memoir, Wiebe has found a way of expressing how a culture produces a Christian way of life that is readily accessible to all its members.

Why should Wiebe's 1962 novel be so troubled—with Hal, its "bright light," barely visible - and his 2006 memoir so untroubled? Why should the two works manifest such astonishing differences-in tone, attitude, and content, in textures and tensions, in how Wiebe negotiates the spaces involving himself, his material, and his audience?

The differences have something to do with Wiebe, without telling anyone, having conflated two historic venues in his novel. Although the novel is manifestly set in the remote Saskatchewan boreal forest of the 1934-47 memoir, it in fact draws also on the politics of the Mennonite church and community to which the Wiebe family moved in May 1947, when Wiebe was thirteen, and where Wiebe grew up as a teenager and young adult. The astringent world defined of Deacon Block of the novel, for example, is actually drawn from Wiebe's bitter experiences of church elders that he observed in southern Alberta, where his family moved in May 1947. Spiritually speaking, it is essentially the "Hal" portions of the novel that conform with the broad outlines and the delicious depths of the very place where the memoir is set.

But the differences are partly a function also of the passage of time-for example, of the respective eras in which Wiebe is writing. Thus they are a function, possibly, of the late modernism still exerting its assumptions in a novel that was written during the late fifties and early sixties, and of the postmodernism informing the leisurely and non-judgmental recollections of memoir. 
The differences are partly a function, too, of the change in genre and the concomitant change in centres of subjectivity. These are a function of conventions affecting literary forms, as Wiebe moves from the urgently programmatic novel written in the third person and centring on an earnest and anxious young adult to the reverie of first-person memoir. The memoir as genre invites the author to respond to his place as a child in an exotic world of strange immigrants at great remove from the typical Canadian reader. Indeed, it is almost a world of an "Other," for in many ways it is remote even from Wiebe's own place in the urban and urbane world of city and university, and of national and international reputation. In reality, his "Mennonite" life has become grafted onto his professional life in a very wide world. Yet, too, signifier and signified seem to stand close together and their differences seem almost to dissolve in Wiebe's memoir, and so the exotic "Otherness" is simultaneously made intimate, just as ironic distance between the world of the child and adult is muted.

The differences partly have something to do with the status of the writer, with the changed socio-cultural position of the writer within various public (including literary and religious) spheres, with Wiebe himself having graduated, as it were, from the role of a "young theologian" (to quote from jacket blurbs) in his twenties when he wrote his first novel as a kind of angry young man to what reviewers now regularly call "one of Canada's most gifted writers," a tried and true writer who is now in his seventies, a writer known for his interest in pursuing empathetically the remote and hidden voices of the unknown Canadian - in the memoir, vividly pursuing his own formative voice (6). ${ }^{6}$

The differences have something to do with Wiebe as a master artist now free and easy within an apparently tension-free world untouched by debilitating rancour and obsessive control, where he has time to follow the dramatic rhythms of satisfying reflection, of shapes of beckoning images awaiting attention in old family photo albums. He is demonstrably performing being at ease now, unfazed by bits of forgetting, happily prepared to announce a memory gap as a memory gap. Even though Wiebe is known for work saturated in his meticulous historical research, for work that draws (although sometimes not without irony) on "fact," he foregoes the illusion of managing an air-tight mastery of facts in the memoir. His emphasis on an infant's inevitable immersion into a bath of language notwithstanding, he avoids absolute readings of the self as child.

6 Wiebe's famous short story "Where Is the Voice Coming From?" provides his paradigmatic summation of his stance as a writer in pursuit of silenced-and only partially and complicatedly retrievable-voices. 
The differences have something to do, too, with Wiebe's own longing. Wiebe clearly takes enormous joy in playfully creating the world of the child. In his memoir he explores the child to give vast scope to his reading of the human subject more generally. For him, as for Carolyn Steedman, writing on autobiography, childhood provides a privileged entry point into "the human subject, of locating it in time and chronology, and 'explaining' it." And through his 2006 exploration of a Mennonite childhood, Wiebe finds a means of connecting subjectivity-and his own history of subjectivity - to the broader culture, one that foregrounds his Mennonite culture (Steedman 11, 13).

Eventually, the young child of the memoir presumably will gather up some of the language keys that, if he enters a world (even a religious world) close to what Wiebe understands today, will eventually make life (and religion) comprehensible to him in generous and gentle linguistic terms. He will get there by a circuitous and leisurely route, happily and unselfconsciously inviting the adult reader along-even if the adult reader chuckles knowingly at the touches of innocence that he/she, but not the boy, can understand as provisional. It is a meandering and easy-going route that is unlikely to bring the boy of the memoir into the tense confines that a Thom Wiens portrays in the 1962 novel.

of this earth - as though an adaptation and expansion of Hal's crystalline and submerged presence in the repressed creases of Peace Shall Destroy Many — gives the reader a new view of the childhood world of Wiebe: a new centre, new suggestions of figure and ground, a new balance. And, at the same time, the memoir invites us to return to Peace Shall Destroy Many with new eyes. It unlocks and makes explicit some of the novel's apparently only implicit treasures and sweetnesses. It invites us to see the novel - indeed, to see the 1962 "Wiebe" himself-as though (to draw on the Eliot of my epigraph) for the first time.

\section{WORKS CITED}

Steedman, Carolyn. Past Tenses: Essays on Writing, Autobiography and History. London: Rivers Oram, 1992.

Tiessen, Hildegard E. “A Mighty Inner River: 'Peace' in the Early Fiction of Rudy Wiebe." The Canadian Novel: Here and Now. Ed. John Moss. Toronto: NC, 1978. 169-81.

Toorn, Penny van. Rudy Wiebe and the Historicity of the Word. Edmonton: University of Alberta Press, 1995. 
Wiebe, Rudy. "An Author Speaks about His Novel." A Voice in the Land: Essays by and about Rudy Wiebe. Ed. W.J. Keith. Edmonton: NeWest, 1981. 64-68.

---. of this earth: A Mennonite Boybood in the Boreal Forest. Toronto: Knopf, 2006.

---. Peace Shall Destroy Many. Toronto: McClelland, 1962. Grand Rapids, MI: Eerdmans, 1964.

---. "The Skull in the Swamp.” Journal of Mennonite Studies 5 (1987): $8-20$. 